ment by the medical profession in all matters affecting the conditions of its academic life. It is for the community to provide the apparatus of medicine for the doctor. It is for him to use it freely in accordance with the standards of the profession and the requirements of his oath."

1 Welch, C. E., New England fournal of Medicine, 1973, 288, 292.

2 Lancet, 1974, 1, 60.

Brook, R. H., and Appel, F. A., New England fournal of Medicine, 1973, 288, 1323.

4 Klein, R., British Medical fournal, 1973, 2, 528.

5 Klein, R., Complaints against Doctors. London, Knight, 1973.

6 Klein, R., New Society, 17 January 1974, p. 130.

7 Dollery, C. T., in Challenges for Change, ed. G. Mclachlan. London, Nuffield Provincial Hospitals Trust, Oxford University Press, 1971.

8 McIntyre, N., British Medical fournal, 1973, 2, 598.

9 Peterson, P., Fournal of the American Medical Association, 1973, 224, 884.

10 Peterson, P., Fournal of the American

10 Weed, L., unpublished observations.

12 Bevan, A., cited by Dunlop, D., in Medical Annual, 1972. Bristol, Wright, 1972 .

\section{Diagnosis of Rubella}

Acquired rubella is a trivial disease. A few swollen glands, a little suffusion of the eyes, slight catarrh perhaps, and spotsthe average attack amounts to little more; but for the spots many patients would scarcely realize they were ill. Many rubella infections are inapparent, so that clinical diagnosis is not possible; but as C. S. Peckham points out in her article on p. 259 inapparent and clinically manifest infections with rubella virus in pregnant women may differ in their liability to cause damage to fetal tissues. The clinical manifestations of the disease are therefore worth studying in some detail.

The rash, which is the most characteristic feature, consists of pale pink macules varying in size from a pinhead to 3 or $4 \mathrm{~mm}$. Their colour is more delicate than the dusky hue of the measles spot and not so fiery red as the erythema of scarlet fever. The spots appear first on the face, usually only a few in number, though occasionally both cheeks are flushed with an almost continuous rash. On the trunk there is often only a thin sprinkling of spots to begin with, but within 12 hours they are scattered all over and spilling on to the limbs. The spots usually remain discrete, especially on the limbs, but sometimes on the trunk they run together to give a general reddening of the skin, but without the puncta of scarlet fever. In an epidemic one gets accustomed to the delicate pink appearance of the rash, but in sporadic cases it can be difficult to distinguish from that of early measles or mild scarlet fever.

Enlargement of lymph nodes is a very constant finding and usually precedes the rash, perhaps for as long as a week. In the neck the suboccipital group, the postauricular mastoid group, and the chain along the posterior edge of the sternomastoid muscle are most often affected, the nodes in the anterior triangle less frequently. The enlargement is usually slight, and in a thick neck the nodes can be difficult to feel; but they can be seen like little grapes under the skin of a thin patient. They are not very tender, but patients usually are aware of their presence and often complain of a stiff neck. Tenderness of lymph nodes disappears quickly, but the enlargement may still be palpable several weeks after the illness.

The mucous membranes of the mouth are pale and clean, quite different from the congested and dusky red appearance in measles. The fauces are often a little injected and in some patients, usually adult women, there may be a few flecks of exudate on the tonsil. This exudate may lead to confusion with scarlet fever if the rubella rash is slightly atypical and especially if the woman has some mild arthralgia of the small joints of the hands: such arthralgia has been a feature in some epidemics of rubella. It is wise to take a throat swab: haemolytic streptococci will be abundant in scarlet fever, but absent or in negligible number in rubella. The conjunctivae in rubella are often suffused with faint pink, but there is none of the acute conjunctivitis seen in measles.

The diagnosis of rubella can sometimes be made with ease, especially during epidemics. Inapparent rubella can be diagnosed only by serological tests. There are several difficulties. If a pregnant woman is known to be seronegative before possible exposure a rise in titre after exposure is diagnostic. Often the original immune status is not known, and one subsequent serological test may be difficult to interpret. The time interval can be important, for IgM appears early but disappears a few weeks after infection, whereas IgG appears later but tends to persist, so that if $\operatorname{IgM}$ is detected in the serum it has probably been provoked by recent infection. ${ }^{1-6}$ Reinfection with rubella virus can occur both in women who have previously had an attack of rubella and in women immunized by vaccine. ${ }^{7-9}$ Such reinfections are usually inapparent, and they appear to provoke IgG antibodies but not IgM. Something can therefore be deduced by careful serological testing - and the interpretation can be of vital importance to the pregnant woman and the unborn child. Clinician and microbiologist must study the findings together. ${ }^{10} 11$

1 Best, J. M., Banatvala, J. E., and Watson, D., Lancet, 1969, 2, 65.

2 Lancet, 1969, 2, 90.

${ }^{3}$ Vesikaris, T., and Vaheri, A., British Medical fournal, 1968, 1, 221.

4 Cohen, S. M., Ducharme, C. P., Carpenter, C. A., and Deibel, R., Fournal of Laboratory and Clinical Medicine, 1968, 72, 760.

5 Burgin-Wolff, A., Hernandez, R., and Just, M., Lancet, 1971, 2, 1278.

- Banatvala, J. E., Best, J. M., Bertrand, J., Bowern, N. A. and Hudson, S. M., British Medical fournal, 1970, 3, 247.

7 Boué, A., Nicolas, A., and Montagnon, B., Lancet, 1971, 1, 1251.

8 Horstmann, D. M., Liebhaber, H., Le Bouvier, G. L., Rosenberg, D. A. and Halstead, S. B., New England Fournal of Medicine, 1970, 283, 771.

- Lapinleimu, K., Pyhala, R., Siimes, K., and Heigl, Z., Scandinavian Fournal of Infectious Disease, 1972, 4, 173.

10 Dudgeon, J. A., Public Health, 1972, 86, 207.

11 Dudgeon, J. A., Peckham, C. S., Marshall, W. C., Smithells, R. W., and Sheppard, S., Health Trends, 1973, 5, 75.

\section{White Marks on Nails}

White spots on the nails are usually of no significance-they may be the result of a very minor trauma. Occasionally pushing back the cuticle during manicure will result in white lines extending right across the nail in series separated by areas of normal pink nail. The appearance in these cases is always very white. The white stripes seen in chronic arsenical poisoning are usually known as Mees's stripes, ${ }^{1}$ though they had been described earlier by F. Sabin. ${ }^{2}$

In $1954 \mathrm{R}$. Terry $^{3}$ noted that the whole nail plate may become very pale in chronic liver disease, and in $1956 \mathrm{R}$. C. Muehrcke ${ }^{4}$ described narrow white bands parallel to the lunule in severe chronic hypoalbuminaemia due to chronic renal disease. Ten years later J. B. Hudson and A. J. Dennis drew attention ${ }^{5}$ to transverse white lines on the nails in both acute and chronic renal failure. The half-and-half nail ${ }^{6}$ is a condition where the proximal half of the nail is pale or white and the distal half is darker than normal. This too is seen in renal failure.

A further cause of white lines has now been reported 7 by R. T. Shanhani and E. K. Blackburn. They noted two white bands separated by bands of normal pink colour on the nails 